\title{
A List Beyond Words: The JOM Top Ten Greatest Works of Materials Fiction Revealed
} Lynne Robinson

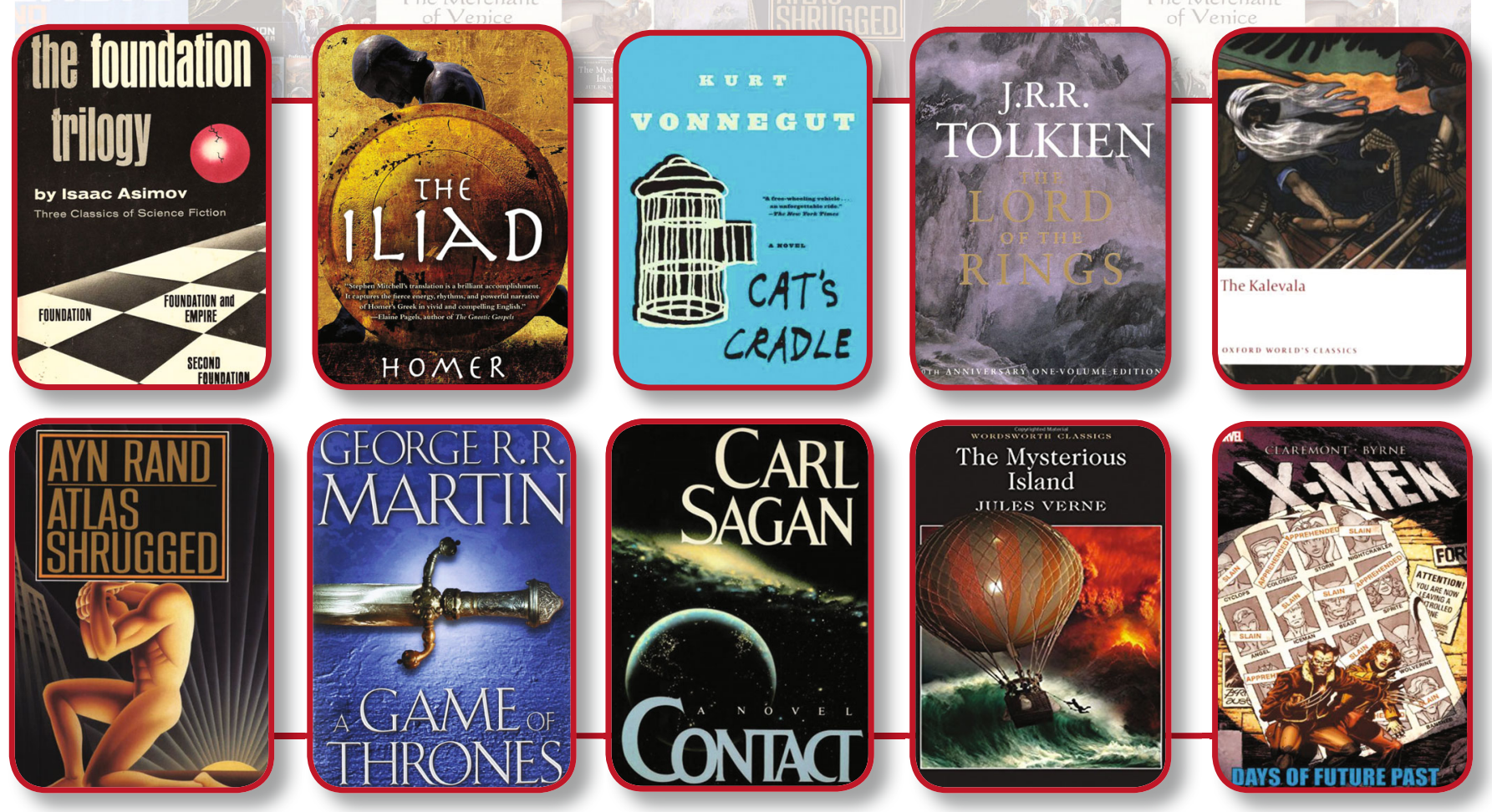

A great work of written fiction demands partnership between the reader and author. Worlds become real as the word painting created by the author joins with the reader's imagination to create a totally unique, immersive inner landscape. This is why we love (or despise) the characters we meet so deeply, why the themes and ideas presented move us so profoundly, and why it is so hard to leave those worlds behind once we have finished the last page. Unlike many other forms of media, what we experience through written fiction is very much a product of our own hearts and minds.

True delight is when a work of fiction resonates with your own life, drawing you in even more as you recognize familiar places, patterns, and idioms. That was the particular intersection that the JOM Materials Fiction Countdown targeted - great written fiction that also celebrated the impact that minerals, metals, and materials science and engineering has on the world, real and imagined.

$J O M$ readers embraced the challenge, from submitting
62 initial candidates (see the complete list on the next page) in late 2014 to voting by the hundreds between February 1 and March 20, 2015 to select the Top Ten Greatest Works of Materials Fiction.

Like all "greatest of" lists, the Top Ten Greatest Works of Materials Fiction, presented on the following pages, will probably be a source of friendly debate for months to come. To provide context for these inevitable discussions, each of the entries on the list is reviewed by a JOM reader sharing his or her particular passion for the piece, as well as insights into its materials connection.

Some of those that made it to the top ten are surprising, a few are obscure, and most certainly don't represent everybody's favorite choice. However, they are all worthy of consideration the next time a long plane ride, a snowbound evening, or a lazy afternoon opens an opportunity to enter a totally different realm, where the fortunes of heroes, the fate of civilizations, and the trajectory of plot lines hinge on the production, use, and perception of materials. 


\section{The Original 62 JOMM MATERIALS}

The $J O M$ editorial team made a general request to readers to submit nominations for the JOM Materials Fiction Countdown in September 2014. After suggestions that did not fit the criteria of original published fiction and duplicate nominees were removed, 62 candidates remained standing. From there, an ad hoc committee appointed by the TMS Board of Directors distilled the list down to the 25 strongest nomineesin terms of their connection to minerals, metals, and materials science and engineering - for final voting of the Top Ten Greatest Works of Materials Fiction of all time.

What follows is the list of the original 62 candidates, with an asterisk $(*)$ indicating the ones that appeared on the final ballot of 25 nominees.

\section{0,000 Leagues Under the Sea: Jules Verne}

Airframe: Michael Crichton

Arsenic and Old Lace: Joseph Kesselring Atlas Shrugged: Ayn Rand*

Building Harlequin's Moon: Larry Niven and Brenda Cooper

Cat's Cradle: Kurt Vonnegut*

Caves of Steel: Isaac Asimov

Contact: Carl Sagan ${ }^{*}$

Copernick's Rebellion: Leo Frankowski

The Cross-Time Engineer: Leo Frankowski ${ }^{*}$

Crystal Singer (trilogy): Anne McCaffrey

The Dark Is Rising: Susan Cooper

The Dark Knight Returns: Frank Miller*

Daughter of Fortune: Isabella Allende

Days of Future Past: Chris Claremont and John Byrne*

The Diamond Age: Neal Stephenson ${ }^{*}$

Dragonriders of Pern (series): Anne McCaffrey

Dragon's Egg/Starquake: Robert L. Forward*

Dune: Frank Herbert

Fail-Safe: Eugene Burdick and Harvey Wheeler

"Farewell to the Master": Harry Bates

The First Patient: Michael Palmer

Flatland: Edwin A. Abbott

The Forever War: Joe Haldeman

Foundation (trilogy): Isaac Asimov*

Fountains of Paradise: Arthur C. Clarke

A Game of Thrones (A Song of Ice and Fire series): George R.R. Martin*

Garret P.I. (series): Glen Cook

"The Gold Bug": Edgar Allen Poe

His Dark Materials (trilogy): Philip Pullman
The Hobbit: J.R.R. Tolkien

The Hunt for Red October: Tom Clancy

The lliad: Homer*

Iron Giant: Ted Hughes*

The Kalevala: Elias Lönnrot*

Killer Instinct: Joseph Finder

King Solomon's Mines: Sir H. Rider Haggard

Lord of the Rings (trilogy): J.R.R. Tolkien*

The Magic Engineer: L.E. Modesitt, Jr.*

Mars (trilogy): Kim Stanley Robinson*

McTeague: Frank Norris

The Merchant of Venice: William Shakespeare*

Mercury: Ben Bova

Mistborn (trilogy): Brandon Sanderson

The Mote in God's Eye: Larry Niven and Jerry Pournelle

Mysterious Island: Jules Verne*

No Highway: Nevil Shute*

Old Man's War: John Scalzi

Poseidon's Arrow: Clive Cussler and Dirk Cussler*

Prey: Michael Crichton

"Profession": Isaac Asimov*

Ramayana: Valmiki

Ringworld(series): Larry Niven

River God: Wilbur Smith*

The Rock Rats: Ben Bova

"Semplica Girl Diaries": George Saunders

Sinclair, Wonder Bear: Malorie Blackman*

Spinward Fringe: Randolph Lalonde

Sublimation: W.M. Goldberger*

Survivors (Dinosaur Planet series): Anne McCaffrey

The Vanished Diamond: Star of the South: Jules Verne*

The Watchmen: Alan Moore 


\section{Days of Future Past \\ By Chris Claremont and John Byrne}

"Once upon a time, it was a nice place to live. It is no longer ... Welcome to the 21 st Century." This is the ominous beginning of Days of Future Past, The Uncanny X-Men \#141-142. First published in 1981, it tells the tale of a bleak, apocalyptic future (the then far-off year of 2013) where sentient robots called Sentinels have eradicated the majority of humans with mutant superpowers in North America, and have subjected the rest to concentration camps. A few mutant heroes, known as X-Men, remain and together they hatch a bold strategy to send Kitty Pryde (who can phase-shift her body to pass through solid objects) back in time to 1980 to disrupt the events that have led to this repression and hopefully create a new, better future.

This now classic story is chock-full of multiple references to the structure and properties of metallic materials. The metal-based powers of Wolverine, whose skeleton has been bonded with the fictional material, adamantium, are portrayed as such: “... gleaming adamantium claws pop out of the back of Wolverine's hands. These retractable claws are forged of the strongest metal known - one far stronger than the Sentinels' omnium steel bodies. Likewise, his entire skeleton is laced with the same miracle metal, making his bones virtually unbreakable." Later in the story, Storm, a character who can control the weather, performs some smelting ("This lightning bolt should reduce the Sentinel's computer brain to so much slag.") and demonstrates knowledge of the ductile-to-brittle transition of the Sentinel's skin (“...with a fearsome blizzard dropping its surface temperature far below zero in a matter of seconds, making its metal skin dangerously brittle. One punch from Colossus will shatter it."). The Colossus character mentioned can also change his flesh into steel at will.

As a metallurgist, I stand tremendously proud that the fundamentals of my discipline are so well represented in these legendary comics.

From a personal perspective, a number of ideas presented in Days of Future Past resonate with me. On the surface, a story about timetravel, a dark future, and killer robots is mundane by today's standards. An astonishing aspect of this story, however, is how unusually prescient this and other themes were in 1981. On the positive side, the X-Men comics, since their inception, have used the mutant metaphor to represent all manners of alienation and discrimination, and the persistent fight against these. We are still fighting for equality and diversity, and in this story, both the hero and villain teams are deliberately depicted as being diverse and led by strong, capable women (Storm and Mystique, a shapeshifting mutant).

On a more negative note, and similar to the consequences of the story, the world is now a place where fear can easily be used to seed reactionary responses with unpredictable consequences. Scientists and engineers created the Sentinels in hopes of making the world a "better" place, yet unknowingly, they initiated the source of its decline. In the end, I advocate that you read Days of Future Past as not just a great work of literature and materials fiction, but as a cautionary tale about the possible future of both society and technology, with the hope that " ... at least we can try that this nightmare never happens, never even begins!" It is our role as members of TMS to make the world a better place, and since we can't time travel (yet?), the time to start creating a better 21 st century for all is NOW.

- Suveen N. Mathaudhu, Assistant Professor, Mechanical Engineering Department, Materials Science and Engineering Program, University of California, Riverside

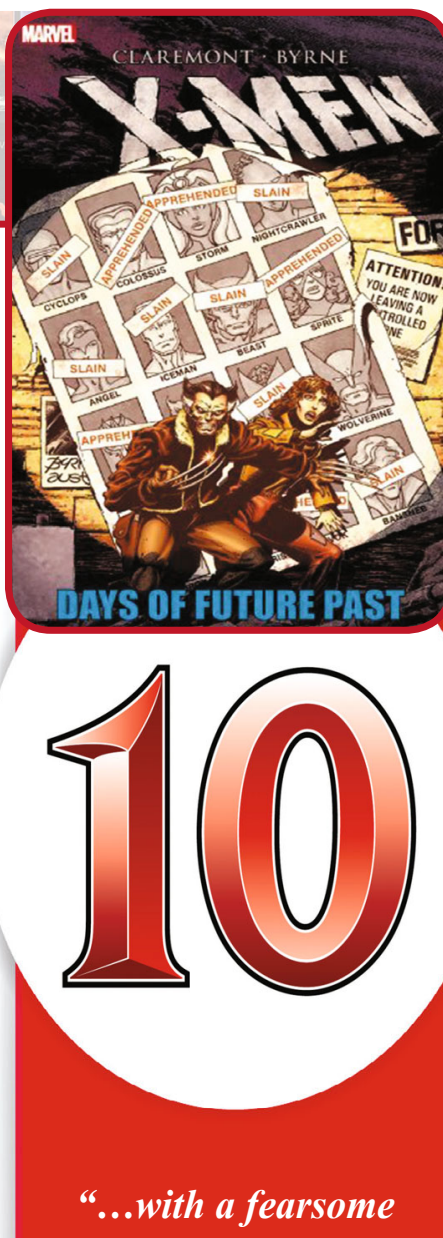

blizzard dropping its

surface temperature

far below zero in a

matter of seconds,

making its metal skin

dangerously brittle."

—Days of Future Past

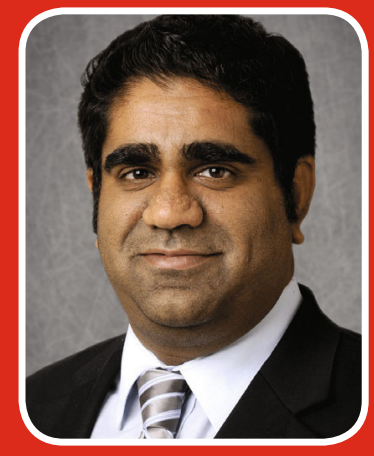

Suveen N. Mathaudhu, Reviewer 


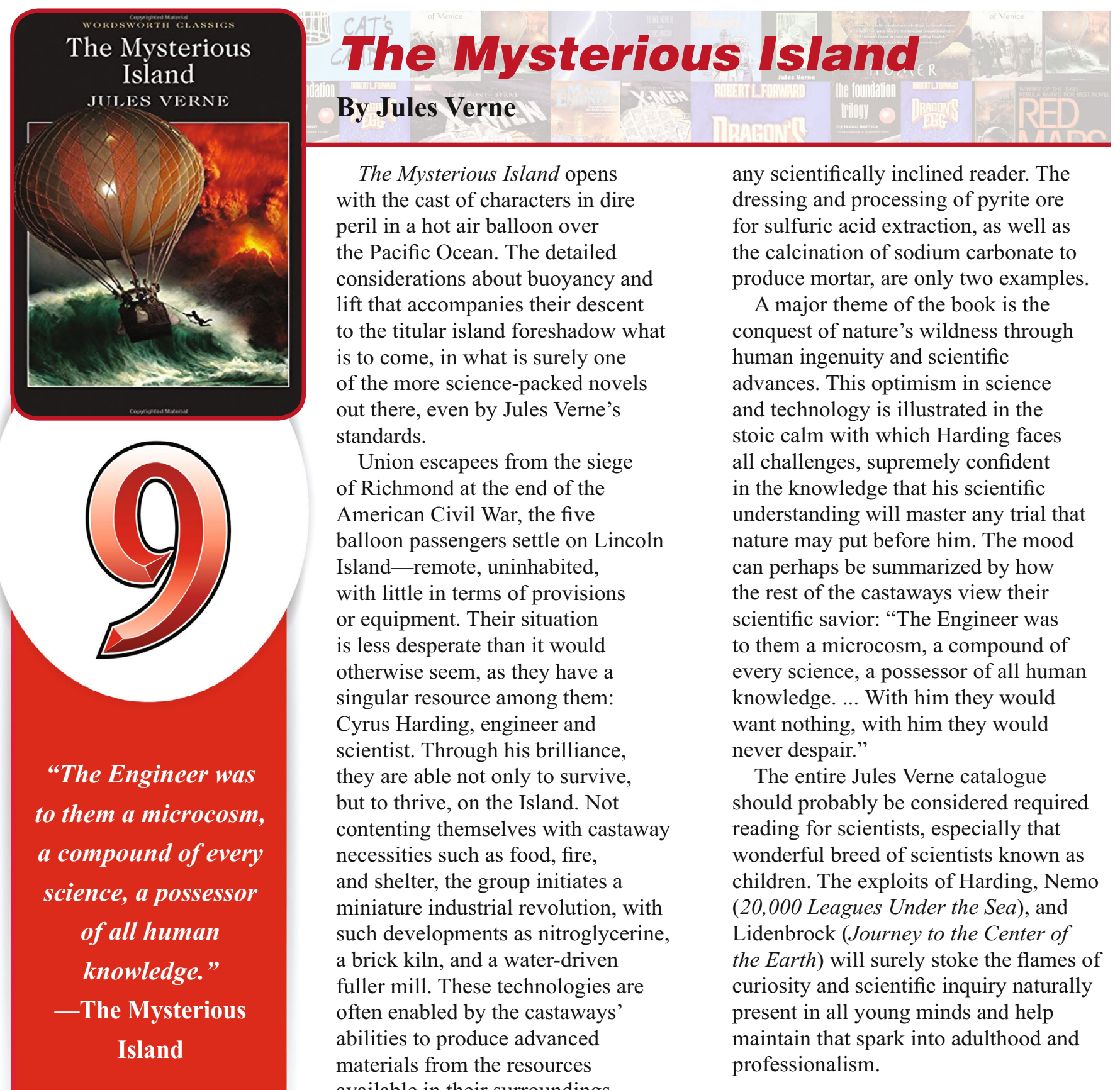

available in their surroundings.

The detail with which Verne describes how these materials problems are resolved will delight

- Halvor Dalaker, Senior Research Scientist, Sintef Materials and

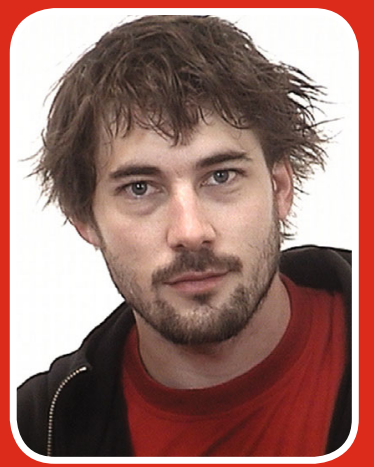
Chemistry 


\section{Contact}

By Carl Sagan

Carl Sagan's main interest in writing Contact - his only work of fiction-was to explore how the first contact between humans and an intellectually superior extraterrestrial civilization would occur. The extraterrestrials, in this particular story, make first contact with Earth via radio signals. Embedded in the signals is a prime number sequence providing instructions on how to build a specialized machine. Building the machine requires a multinational effort costing approximately $\$ 4$ trillion over numerous years. Erbium is the main element of the erbium dowel, a critical component of the machine, with two tons of erbium at 96 percent purity required for each of the two machines that are to be built. The extraterrestrials provide directions on how to extract the metal from its ore, as well as detailed instructions for fabricating the high-tech materials and assembling the machine, as illustrated in this passage:

"At every stage of construction there were checkpoints: The erbium produced by this process should be 96 percent pure, with no more than a fraction of a percent impurity from the other rare earths. When Component 31 is completed and placed in a 6 molar solution of hydrofluoric acid, the remaining structural elements should look like the diagram in the accompanying figure. When Component 408 is assembled, application of a two megagauss transverse magnetic field should spin the rotor up to so many revolutions per second before it returns itself to a motionless state. If any of the tests failed, you went back and redid the whole business."

Contact was published in 1985, at a time when two tons of erbium exceeded the annual global supply. With the recent explosion in rare earth element production to support new uses, the four tons extracted to build the machines in this book actually represent less than 20 percent of the current world's annual supply. Sagan is by default realistic, given his unofficial status as the world's foremost advocate of layperson understanding of big picture cosmos and science. (For this reason alone, reading this book is a treat and highly recommended.) Sagan likely came up with the four ton total, cross referencing the erbium composition in the Earth and realizing it was attainable. Nevertheless, it is doubtful that he imagined erbium production for the machine in 2015 would be as easy as submitting a purchase order to the world's erbium producers.

Erbium is not the only metal whose production has multiplied rapidly since Contact was published. Lithium has more than tripled in production. Indium production has increased more than 10 times due to backlit light-emitting diode screens. Rhenium demand has more than quadrupled. Even copper has nearly tripled in production over the last 30 years. Whether to support an increasingly wealthy world population or technological advancement necessitating new materials, professionals involved in the mining, extraction, and development of materials have had to satisfy this demand by pushing the limits of human knowledge. This theme of challenging human limits is actually what attracted me to Sagan's book.

The story line in Contact is one of the thousands that could occur. However, no matter the circumstances of what potentially would be humanity's most defining moment, materials will be front and center of the story. Like all reality, advancement and development is not possible without advances in materials technology and the methods of materials extraction, which is the direct link between this book and our profession.

-Ernest Mast, President and Chief Operating Officer, Primero Mining Corporation
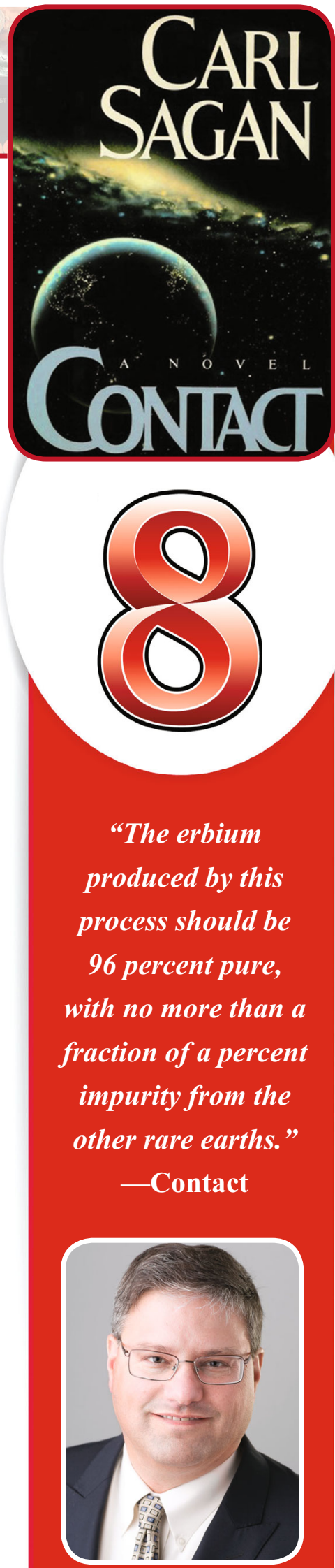

Ernest Mast, Reviewer 


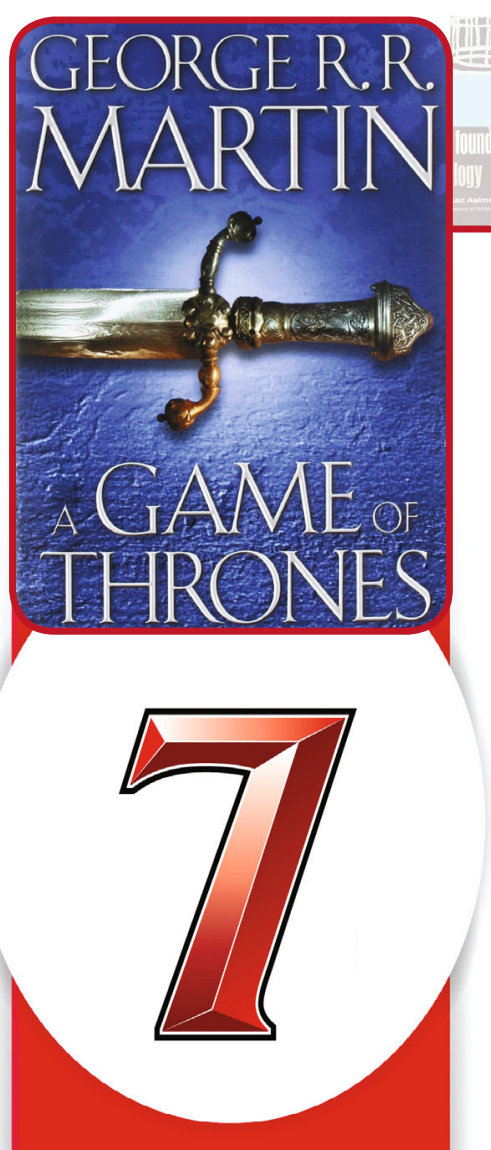

"Robert was the true

steel. Stannis is pure

iron, black and hard and

strong, yes, but brittle,

the way iron gets. . .

And Renly, he's copper,

bright and shiny, pretty

to look at but not worth

all that much at the end

of the day."

—A Clash of Kings

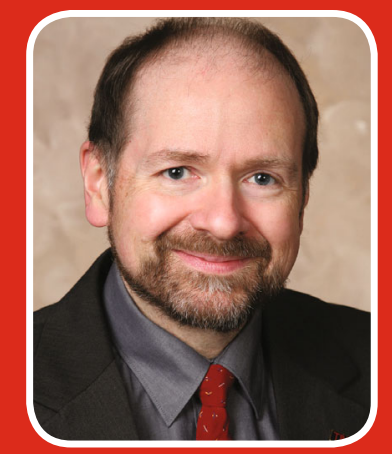

James J. Robinson,

Reviewer

\section{A Song of Ice
By George R.R.Martin}

While I dearly love many of the books in this countdown, my unquestioned favorite is the five- and soon (?) to be seven-volume work comprising $A$ Song of Ice and Fire by George R.R. Martin. Many people reference this epic but-asof-yet unfinished work by the title of the first volume, A Game of Thrones - the namesake of the almost equally brilliant television series. If you are unfamiliar with the work, I'll summarize by saying that $A$ Song of Ice and Fire tells the sprawling, multi-perspectived saga of a Dark Age-ish time when the death of one powerful king leaves a suite of worthy and (mostly) unworthy contenders scrambling to assert legitimacy of rule via intrigue, subterfuge, and battle. There's nobility, war, chivalry, exploitation, compassion, cruelty, enlightenment, barbarism, politics, religion, science, and the preternatural.

Referential to many other literary works without being derivative, the books are exquisitely written and thrillingly rich in textured characterizations, unpredictable storytelling, insights into the heights and abyss of human nature, and the reason for inclusion in this countdown: Iron Age metallurgy. As someone who thrills when a meaningful allusion to materials science or engineering makes an appearance in a book, movie, or other work of art, I have been enkindled by Martin's references to:

- The much-coveted Valyrian steels. Damascene-patterned Valyrian blades are lighter, stronger, and sharper than the blades produced by normal smiths. Valyrian swords are rare, named, and typically in the possession of only the richest men as the technology to make new blades is long vanished. My favorite sword? Longclaw, which was gifted to my second-favorite character, Jon Snow. (My favorite character? Daenerys Targaryen.)

- The "maesters" are effectively the wise men of the period, trained in science, healing, economics, languages, and so forth. A characteristic of a maester is the chain around his neck; the maester forges a new link of a different metal as he develops mastery of a new field. Some of the metals (and their associated disciplines): Black iron (ravenry), bronze (astronomy), copper (history), iron (warcraft), and silver (medicine).

- The religion of the Seven. This faith, one of many prominently featured throughout the series, teaches of a single god consisting of seven individual personages. One personage is the hammer-carrying Smith, the patron of craft and hard work.

- The importance of everyday metalsmiths, good ones and poor ones, to make practical and ornamental armor and wildly elaborate helms, and to straighten and sharpen eroded or war-ravaged blades. My favorite smith is the one-armed Donal Noye, who provides a keen metallurgical assessment of three brothers, all kings in their turn: "Robert was the true steel. Stannis is pure iron, black and hard and strong, yes, but brittle, the way iron gets. He'll break before he bends. And Renly, that one, he's copper, bright and shiny, pretty to look at but not worth all that much at the end of the day." (Book 2: A Clash of Kings).

There's much more than metal to love about the conflict for the Iron Throne, but that's up to you to discover. What's the highest praise I can give to A Song of Ice and Fire? Just this: I know how I want the story to end, but I never want the story to end. Even after 4,273 pages of narrative already published and about 2,000 more still being written, I want this story, like the rich tapestry of life that it depicts, to go on endlessly. Of course, I wouldn't mind if Martin picked up the pace of his writing just a bit.

-James J. Robinson, TMS Executive Director 


\section{Atlas Shrugged}

By Ayn Rand

What causes poverty? This question has started debates, sparked social crusades, and occupied the minds of the wellintentioned for generations. However, as Ayn Rand explores in Atlas Shrugged, this may be the wrong question. Poverty is actually the true default condition: people living in hovels, helpless to the ravages of disease, living short and brutalized lives - this has been history's norm. The true anomaly is prosperity. Atlas Shrugged answers the question, "What causes prosperity?" and helps us understand how we can get more of it.

The story is set in the waning days of an industrial society. Infrastructure is collapsing, new businesses are rare, and standards of living are decreasing. These trends are caused by a philosophy that the society has embraced-one in which the profit motive and private property are despised and redistribution of wealth is seen as the solution. The heroes of this story are those who choose to oppose such notions and pursue lives of creative ingenuity and free enterprise.

For many years, Hank Rearden, an industrialist, pursues the development of "a metal alloy that would do more than steel had ever done, a metal that would be to steel what steel had been to iron." At last he creates it — an alloy system with magnificent properties, including an unprecedented strengthto-weight ratio. Though the metal and its properties are fiction, the story line illustrates the revolutionary potential of materials research. In design, materials are typically the limiting constraints, so drastically improved properties can lead to performance improvements in a myriad of products and impact the entire economy.

Atlas Shrugged focuses on the conflict that emerges between those who make breakthroughs like Rearden's metal and those who know no other skill than appropriating the wealth of others. Corrupt government officials and business leaders oppose the use of the metal on the grounds that it will disrupt the economy. (In reality, it is simply unwanted competition to their business interests.) They pressure Rearden to sell the property rights to prevent his alloy from being produced at all. When he refuses, laws are passed to control how much of the metal he can produce and to whom he can sell it. Ultimately, he is blackmailed into signing away the rights.

In the face of such persecution, the entrepreneurs, inventors, and industrialists decide on a course of action familiar to nearly all professions except their own. They go on strike. Those who value free enterprise set aside their work in protest of a society that treats them as robber barons and scoundrels. Rand illustrates her solution to the problem of poverty, via netagiva, by exploring the results of this scenario. As those who serve as society's backbone cease their work, businesses fail one after another and critical goods and services become scarce. When winter hits, life regresses to the pre-industrial baseline - almost universal poverty. Rand writes that widespread prosperity, the anomaly of the industrial era, dissipates quickly when its origin is removed - the freedom of productive and inventive people to pursue profit.

Although metallurgy is used primarily to illustrate Rand's message, Atlas Shrugged captures what I most love about science and engineering and particularly the materials professions. For me, the materials field represents the potential for almost limitless progress. Whatever the technical problem facing humanity, whether it is drought, disease, etc., advancements in materials technology can offer real solutions. I think if you take the time to read this volume, you will feel inspired, as I was, to make the greatest possible impact in your work in the materials science and engineering field.

- David Howe, Graduate Student, Drexel University

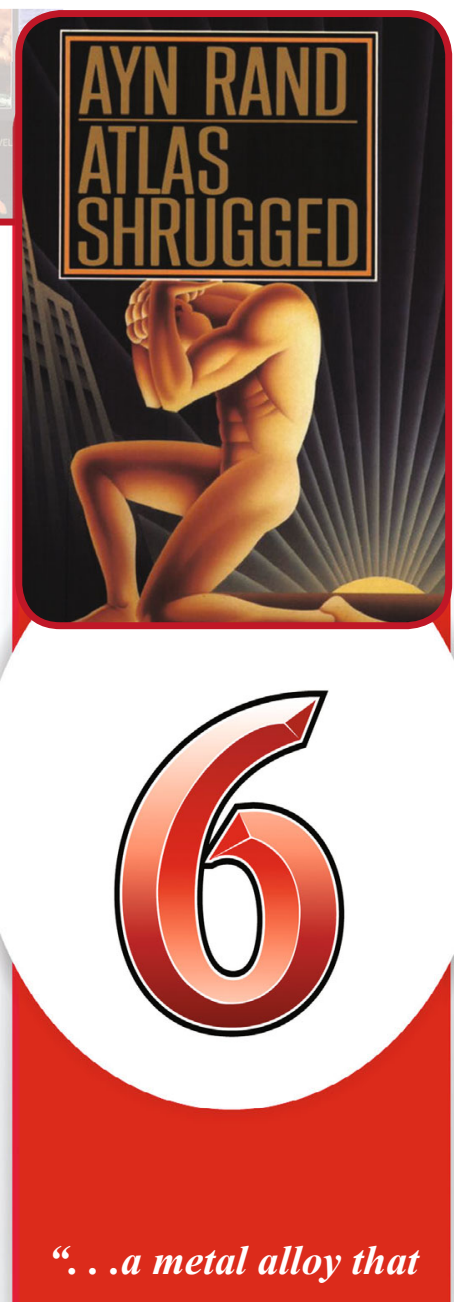

would do more than

steel had ever done,

a metal that would

be to steel what steel
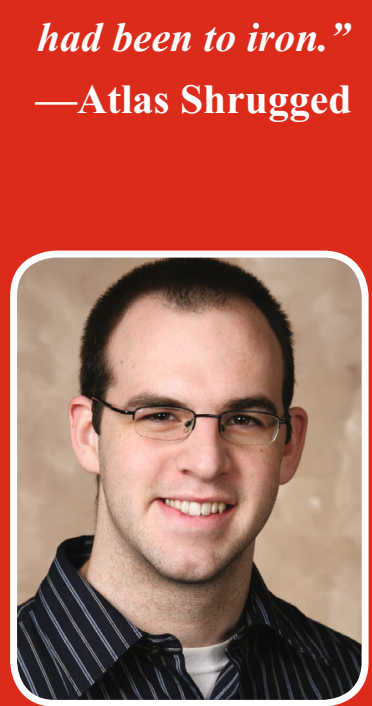

David Howe, Reviewer 


\section{the fountilition Foundation (trilogy)}

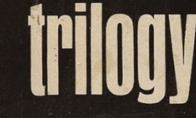

by Isaac Asimov

Three Classics of Science Fiction
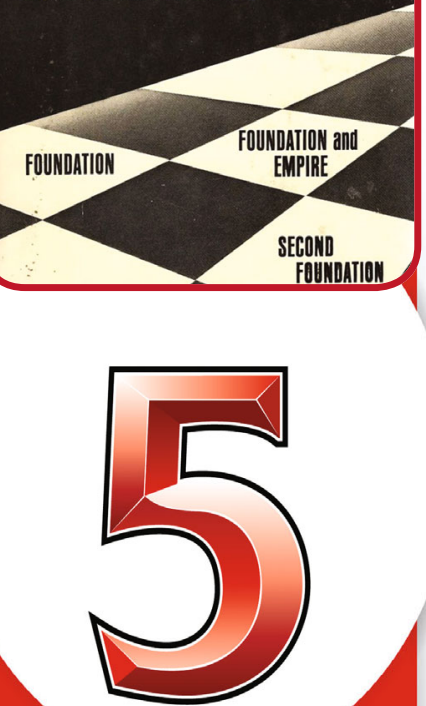

Foundation, our

single world almost

without metallic

resources, have had

to work with brute

economy."

—Foundation

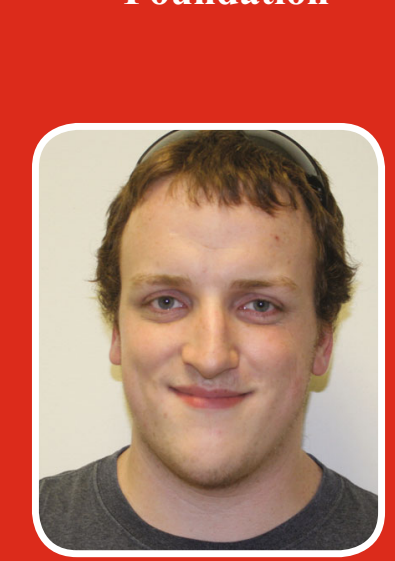

David Freiberg, Reviewer

By Isaac Asimov

The Galactic Empire was dying.

Though its fall had been centuries in the making and could not be stopped by any conceivable means, the great mathematician, Hari Seldon, used psychohistory - a science of statistical psychology - to predict the general trends of future history and find a way to shorten the inevitable period of barbarism that was to follow the collapse: He established two Foundations on opposite sides of the galaxy to act as outposts and reserves of scientific progress. Eventually, they would form the nucleus of a new and better galactic civilization.

Saving scientific knowledge was necessary for achieving this, but not by itself sufficient. In an early scene, a representative of the Empire boasts of his expertise in archeology. Upon further inspection, this expertise is based entirely on the fact that he's read many books on the topic and weighed their respective viewpoints, not that he's gone to any dig sites with trowel and toothbrush in hand to look at the empirical evidence for himself. That neither he nor the people to whom he boasts see any problem with this is used by Asimov as shorthand for the decay of scientific literacy and capability throughout the Galaxy. Given the number of news stories today that look at a medical paper abstract and announce an imminent cure for cancer, that issue is as meaningful now as it was 60-odd years ago.

Because he realized that merely recording past discoveries was not enough to spur scientific discovery, Seldon placed the first Foundation on a planet where the metal supply was so limited that the highest denomination of currency was stainless steel. As metal is essential for any advanced civilization, this
Foundation was forced to adapt, both by trading skills and information for metal with nearby worlds when it might have remained isolationist, and by using what little material it had more efficiently: "The Empire has always been a realm of colossal resources. They've calculated everything in planets, in stellar systems, in whole sectors of the Galaxy. Their generators are gigantic because they thought in gigantic fashion. But we, our little Foundation, our single world almost without metallic resources, have had to work with brute economy. Our generators have had to be the size of our thumb, because it was all the metal we could afford."

Resources are the combination of raw materials and human inventiveness, and by restricting the former, Seldon forced the other to rise to the occasion - which ultimately had the better payoff.

This trilogy of books follows many characters, spans hundreds of years, and reads in some ways like a puzzle - the eventual survival of the Foundations are known in advance but the means of their survival are not. Its theme of scarcity as a driver of innovation is prescient, its commentary on the nature and importance of scientific discovery relevant, and its portrayal of a 1950s version of the future in which everybody smokes, household appliances are powered by miniature nuclear reactors, and microfilm is the latest and greatest way of storing information make it just plain fun. Its planet-wide city, Trantor, inspired George Lucas and its Encyclopedia Galactica inspired Douglas Adams. Foundation is being adapted into an HBO miniseries set to air in 2016 or 2017 — read the trilogy now and you can get revenge on that one friend of yours who spoiled Game of Thrones.

-David Freiberg, Undergraduate Student, Materials Science and Engineering, Drexel University 


\section{The Iliad}

By Homer

When I first saw the question posed by $J O M$ regarding the greatest works of materials fiction, The Iliad instantly came to mind. A refresher quickly reinforced why - metals are at the heart of this epic poem, composed in the early Iron Age, but hearkening back to heroes of the late Bronze Age.

Metals are woven throughout the story regardless of the translation style, whether the poetic Pope, or the scholarly Rieux from which I took these quotes: "On his head, Agamemnon put his helmet, with its four plates, its double crest, and its horsehair plume nodding defiantly above, and finally he picked up a pair of strong and sharp bronze headed spears. Beams from the bronze he wore flashed into the distant sky, and Athene and Here thundered in answer by way of salutation to the King of Golden Mycenae."

Gold, silver, copper and tin are common in The Iliad, but it is bronze that dominates. It kills or preserves on every second page and lives are lost to capture or recover the armor of a fallen hero- - the fight over Patroclus's body is an epic in itself. Bronze is variously "shining," "gleaming," "cruel," "cold," and "relentless." There are fine descriptive passages of armor and arms, of Here's (queen of the gods) chariot, and especially of the smith god, Hephaestus, as he forges new arms for Achilles. Hephaestus even has a pair of intelligent, solid gold, automatons as assistants. Craftsmanship throughout the book is lovingly detailed with woods, enamels, horn, and textiles all prominently featured.

One particular detail resonates with me- "violet" iron is awarded as prizes, in pig form (for ploughshares) and in axes, by Achilles at Patroclus's funeral games. However it is clear that the new metallurgy has not progressed enough to supplant bronze for combat!

Why read it? The first poem of western civilization is distinctly believable. Part of the fascination of The Iliad is that it involves a mere few weeks towards the end of the ten-year Trojan War, and not the actual end itself. Critically, the audience, as they listened, knew the end and this adds immensely to the tragic atmospherefor a book that is close to 3,000 years old it has a very sophisticated storytelling technique.

The poem starts with a childish quarrel between King Agamemnon and his most able leader, Achilles, and Achilles stops fighting to sulk in his tent. As a result, the Greeks are slaughtered until Achilles's friend Patroclus is killed by the Trojan hero, Prince Hector. Achilles returns, kills Hector in revenge, and then holds funeral games for his friend. The book ends with King Priam of Troy, Hector's father, entering the Greek camp and finally touching Achilles's compassion to recover the body of his son. There are no monsters and the interventions of the gods are subtle. This is a poem that highlights the glory but exposes the futility of battle. Achilles knows he has to die to achieve immortality and chooses this over a long, obscure life. These are real, flawed men, as well as heroes.

-Mark Francis, Manager, Stonehouse Hard Materials, NOV Wellbore Technologies

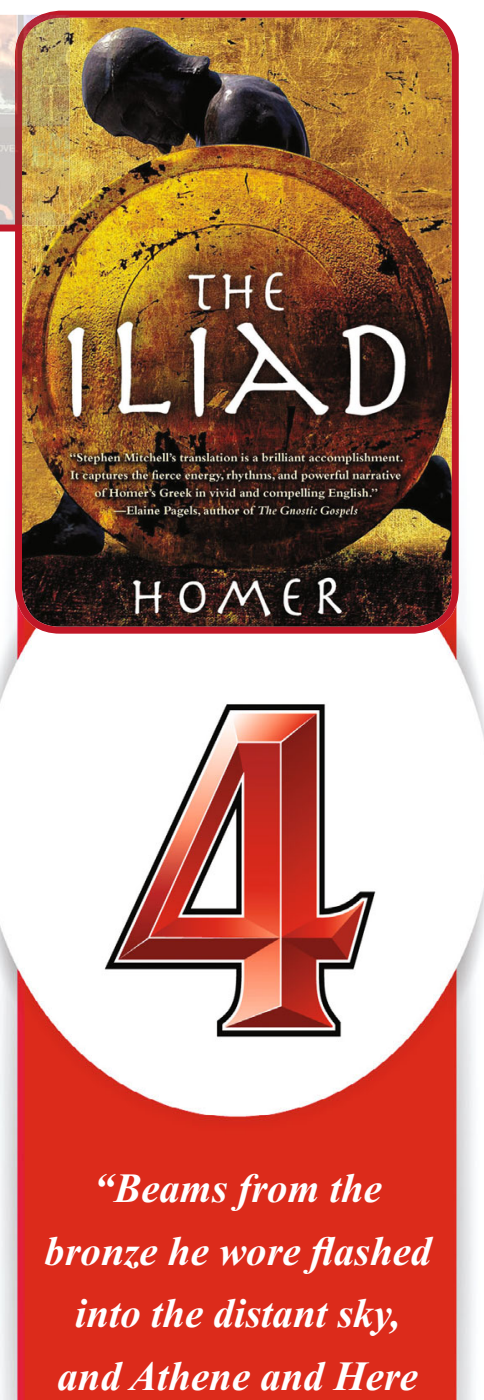

thundered in answer

by way of salutation

to the King of Golden

Mycenae."

-The Iliad

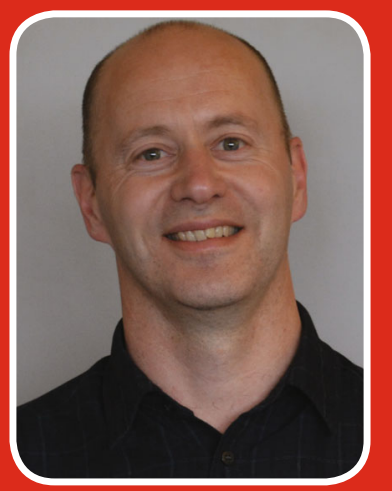

Mark Francis, Reviewer 


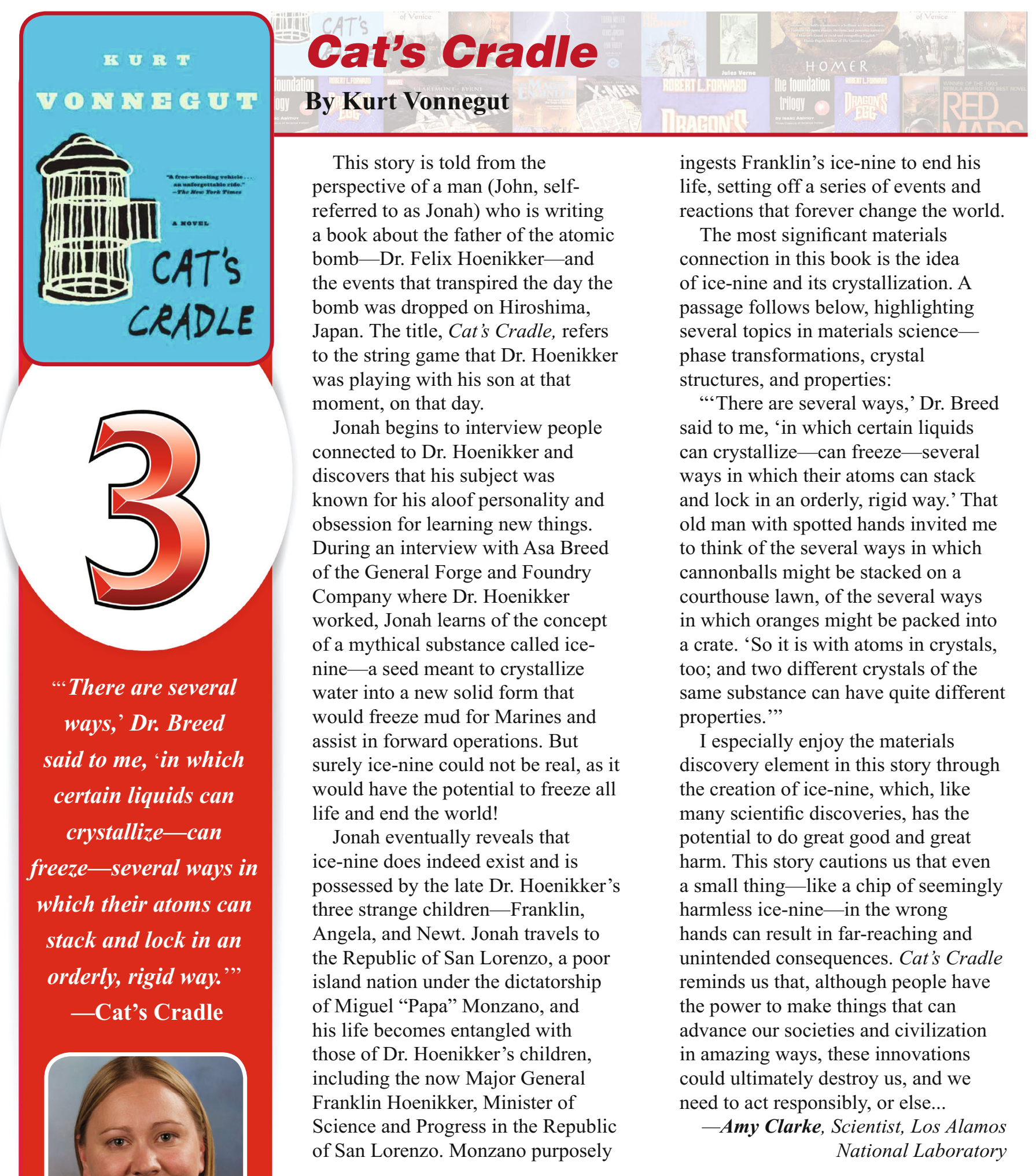




\section{Lord of the Rings (trilogy)}

By J.R.R. Tolkien

In the fictional realm of Middle-Earth, Frodo Baggins, a Hobbit, travels from the peaceful Shire to the fiery volcano of Mount Doom in order to destroy the One Ring. The One Ring was originally forged by the Dark Lord Sauron in the fires of Mount Doom to control MiddleEarth. While no details about the One Ring's exact composition are noted, it appears to be made from gold and is impossible to damage. The only way to destroy it is to return it to the fires from whence it was forged. The One Ring also grants its bearer an unnaturally long life and the power of invisibility. Alongside these magical abilities, the Ring bears an inscription revealed only by fire. On his dangerous quest, Frodo is pursued by the servants of Sauron, who wants to recover the One Ring and use its considerable powers to conquer the realm.

Aside from the One Ring, there are many other fantastic materials that exist in Middle-Earth. One of those is mithril, described by the wizard Gandalf: "Mithril! All folk desired it. It could be beaten like copper, and polished like glass; and the Dwarves could make of it a metal, light and yet harder than tempered steel. Its beauty was like to that of common silver, but the beauty of mithril did not tarnish or grow dim."

Naturally, the metal possessing all of these wonderful and much desired properties was going to be incredibly expensive-It had a value ten times that of gold until the supply disappeared and it became priceless. It was fortunate that Frodo wore a mithril shirt of mail on his quest, as this armor saved his life on multiple occasions. An alloy of mithril called ithildin was used as a decorative inlay, with the interesting quality that it was only visible by starlight or moonlight.

Sadly, there is not space to cover all of the materials presented in Lord of the Rings, like the magical blades that glow in the presence of evil creatures, or cause wounds to soul and flesh alike. Whilst the alloys we use in reality do not possess magical properties, there are many features described in the books which will resonate with those in the study of materials and minerals science.

The Lord of the Rings books were given to me at age 11, long before I was aware of metallurgy, but I was entranced by the magical realm of Hobbits and wizards, with its descriptive adventures and incredible items. Who wouldn't want a magic ring, or a sword that glowed with danger, or the lightest and strongest chain mail imaginable? With the main protagonist being an endearing little person, originating from an often forgotten area and possessing no special power other than a strong will and heart, the tale appeals to the young and old alike. The fact that materials are central to the plot is wonderful to see as a materials scientist, and is a source of inspiration for the next (and current!) generation of scientists.

- Sarah Driver, Graduate Student, University of Cambridge
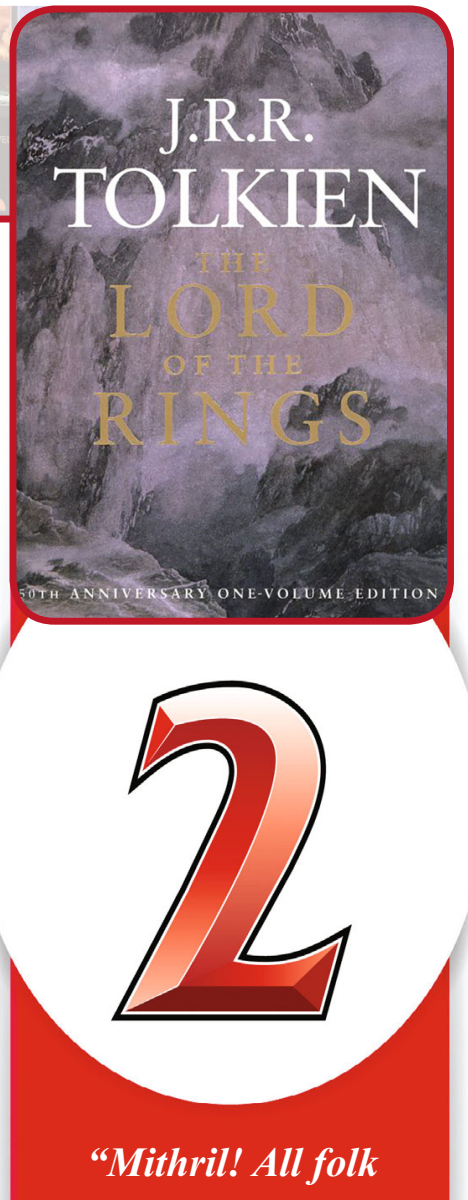

desired it. It could be

beaten like copper, and

polished like glass;

and the Dwarves could

make of it a metal,

light and yet harder

than tempered steel."

- The Fellowship of

the Ring

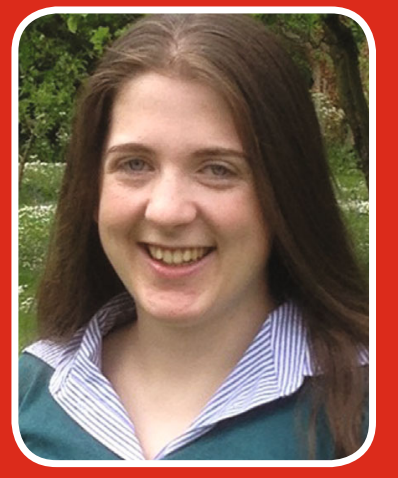

Sarah Driver, Reviewer 


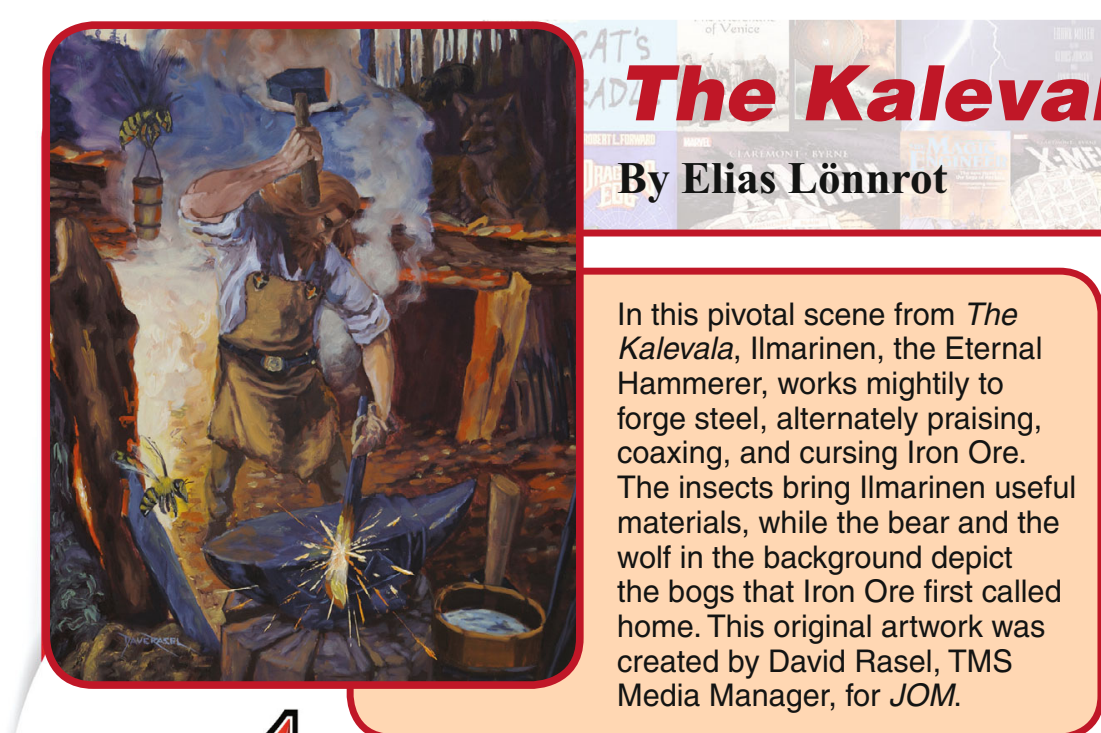

The Kalevala is the national epic of Finland. It is a complicated read, as there is no uniform plot, but rather several sequences that revolve around a main character or a course of events. The main protagonist, Väinämöinen, famous for his wisdom and songs, travels to Pohjola

"Then again speaks Ilmarinen, Thus the smith addresses Iron: 'Be not frightened, useful metal, Surely Fire will not consume thee, Will not burn his youngest brother, Will not harm his nearest kindred. Come thou to my room and furnace, Where the fire is freely burning, Thou wilt live, and grow, and prosper, Wilt become the swords of heroes. .." -Rune IX, The Origin of Iron

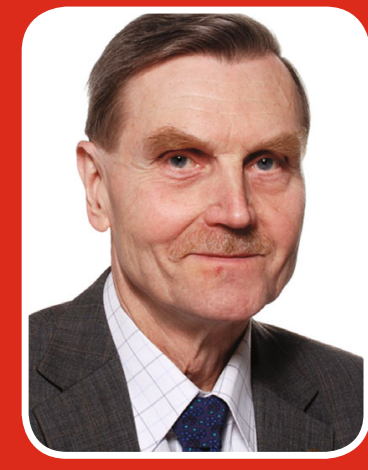

Lauri Holappa, Reviewer
(Northland) and Louhi, the mistress of Pohjola, promises him one of her daughters if he makes her a Sampo, a magical artifact that includes three mills for grinding flour, salt, and money. Väinämöinen pledges to send the mythical and powerful smith, Ilmarinen, to forge the Sampo.

On his way homeward, Väinämöinen tells of the origin of iron (Rune IX), elevating iron to the same stature as the classical elements of air, fire, and water. In this rune, the raw materials, bog ore and charcoal, as well as the smelting furnace, are described. The poem even warns of the risks of the ancient bloomery-type direct iron making that can result in "dark and ductile iron," "iron lighter-colored," or "red and brittle iron." Today, these types of metal are known as malleable steel, hardenable steel, and cast iron, respectively. The struggles and frustrations that Ilmarinen experiences as he experiments with materials and techniques to perfect his metalworking are not that dissimilar to what modern-day materials scientists and engineers encounter in their work.

In Rune X, Ilmarinen, also known as the Eternal Hammerer, forges the Sampo. Louhi is satisfied and hides it, but Väinämöinen, Ilmarinen, and Lemminkäinen try to steal the Sampo. In the fierce battle that ensues, it falls into water and breaks into pieces, fostering the sea. The Sampo is a key, recurring element throughout The Kalevala.

The Kalevala's impact on the arts is endless, both in Finland and worldwide. Among the many works it influenced, The Kalevala inspired J.R.R. Tolkien and his development of Lord of the Rings. In Finland, The Kalevala is beloved and its publication is regarded as a significant milestone in the development of Finland's national identity. In 1809, Finland was separated from Sweden and became an autonomous grand duchy of Russia. This new stature aroused a cultural awakening and a passion to create a national identity. The rich poetry of the Finnish language was understood as a means of accomplishing this, but it was largely uncommitted to paper at the time. Elias Lönnrot (1802-1884) is credited for preserving this important element of Finnish culture by locating rune singers throughout Finland, asking them to sing their poems, writing down the verses, completing the stories, and finally publishing the Old Kalevala in 1835.

It is said that The Kalevala can be understood as a journey of the spirit or the soul. Even materials like iron have a spirit. Ilmarinen, the smith, dialogues with the iron, and when hammering, he affords his own expertise to connect with the secret, hidden properties of the material. These are still today central issues of materials research - although the dialogue has moved to the internet, and the "smiths" have sophisticated scientific instruments to reveal the material's secrets.

- Lauri Holappa,

Professor Emeritus, Aalto University

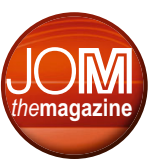

